\title{
Urdubic as a Lingua Franca in the Arab Countries of the Persian Gulf
}

\author{
* Dr. Riaz Hussain, Head \\ ** Dr. Muhamad Asif, Head \\ *** Dr. Muhammad Din
}

\begin{abstract}
A new lingua franca, Urdubic, is emerging in the Arab countries of the Persian Gulf. Its linguistic composition is defined by the reduced and simplified forms of Arabic and Urdu. The paper examines linguistic, social, and historical aspects of its sociolinguistic make-up. Recurrent patterns of mutual migration between Arabs and Indians have played a pivotal role in the development of this lingua franca. Today, it appears to permeate the very homes of the Arabs. The examples of linguistic features (combinations of Urdu and Arabic) of the pidgin mentioned in the current study show that Urban Arabic is accepting foreign influences. This influx of foreign languages has alarmed those Arabs who want to preserve the purity of Arabic. How long Urdubic is going to survive amid Arabs' efforts to save Arabic from such foreign influences? The paper concludes with speculations about the future of Urdubic.
\end{abstract}

Keywords: $\quad$ Pidgins, creoles, Persian Gulf, Arabic, Urdu

Introduction

Change is an integral part of life. There are changes in human society that are noticed at the time of occurrences such as economic reforms and sudden political changes. But, there are finer changes regarding human linguistic behavior that may occur as a result of large-scale social, economic, and political changes and may be noticed only after years of latent development. The emergence of a contact language is such a change. According to Samarin (1968), there are three types of lingua franca: natural, pidginized, and planned, (as cited in Barotchi, 2001). A recent instance of a pidginized lingua franca or a contact language emerging as a result of economic changes is Urdubic. Following the discovery of oil in the Arab countries of the Persian Gulf, there seems to have emerged a pidginized lingua franca in an environment of linguistic heterogeneity as a result of large-scale immigration of workers from South-Asia. It seems germane to mention here that Urdu and Hindi are often regarded as the same language. Their different writing systems and religious associations seem to make them appear different.

The new pidgin in the Gulf has been given different names such as Gulf Pidgin, Gulf Pidgin Arabic, Hindi Arabic, and Urdubic. Avram (2014), Alghamdi (2014) Alshammari (2018). And Abed (2018) link the development of this new language to economic integration and the arrival of immigrant workers in the Persian Gulf. Smart (1990) explains that this lingua franca is used by a constantly changing force of temporary immigrant workers in everyday communication with their Arab masters. The words constantly changing are significant and refer to the temporary stay of workers in the region. This constantly changing force includes doctors, engineers, teachers, laborers, technicians, drivers, waiters, maids, cooks, cleaners, sweepers, gardeners, salespersons, barbers, and others. Though this lingua franca came to the fore with the oil boom, the traces of its latent existence can be noticed even before the discovery of oil. According to Badry of the American University of Sharjah, this lingua franca existed in some form for a long time because of the Gulf's history as a trade hub (as cited in Zacharias, May 2, 2010.) Let us try to examine the role of the Persian Gulf as a trade hub where Urdubic evolved throughout history.

\footnotetext{
* Department of English Linguistics, Islamia University of Bahahwalpur Email: dr.riazhussain@iub.edu.pk

** Department of English, Ghazi University, DG Khan Email: uasif@gudgkedu.pk

*** Department of English, Government Postgraduate College Burewala Email: mduaau@gmail.com
} 


\section{Historical Background of Urdubic:}

As a trade hub, the Persian Gulf has been attracting people from the surrounding regions for centuries. The visits of foreign travelers, traders, workers, and navies changed this trading hub into a place where people could speak and understand different languages. Ammon, Dittmar, Mattheier \& Trudgill (2006) argue that the linguistic consequences of this long-term ethnic mixing have been considerable and have affected both the lexical stock and the morpho-syntax of the Gulf dialects. This is in sharp contrast to the dialects of central Arabia, which were much less exposed to external influences. In this ethnic mixing which included languages from Europe, Africa, and Asia; two languages enjoyed close geographical and linguistic proximity-- Persian and Urdu/Hindi. According to Dil (2003), Hindi is so close to Urdu in its colloquial forms that a prominent linguist has called Urdu 'virtually the same language as Hindi. It may be due to this colloquial closeness that Pakistani, Indians, and Bengali immigrant workers working in the Persian Gulf, seem to be linked together with the same lingua franca that linked the Indian people before the partition of 1947.

The trade, cultural and religious relations between the Arabs and the people of the Indian subcontinent seem to date back to pre-historic times. Khan (2006) thinks that the Mesopotamian farmers of the rich lands of the Euphrates and the Tigris were the parents of Urdu / Hindi. He believes that these farmers, who brought barley, wheat, and technology to the Indian sub-continent, must have generated the earliest hybrid(s), Proto-Urdu/Hindi. However, this Mesopotamian influence remained latent in the sub-continent until the Muslim rule started in India and Urdu emerged as a lingua franca in the Indian sub-continent combining the features of Arabic, Persian, and the local Indian languages. With the spread of Islam beyond the Arabian Peninsula, Arab Muslim traders, travelers, seafarers, preachers, Sufis, scholars, and conquerors began to arrive in India. Some of these traders, conquerors, and preachers held marriages with local Indian women and settled there. The trade relations between India and the Persian Gulf, which had existed before Islam, strengthened. The classical Arabic literature of the pre-Islamic period mentions traditional Indian weapons and swords. The very names of the varieties of these words speak of their Indian origin: muhannad, Saif al-Hind, Hindi, and Saif Muhannadani (Sherwani, Joshi \& Nayeem 1975). Enumerating the other items exchanged in the IndoArab trade, Wink (2002) explains that spices ointments, perfumes, gold, and slaves were exported to Arabia while horses, copper, lead, paper, carpets, glass, and chemicals were exported from Arab lands to India. He further points out that during the Abbasid period, the Indo-Arab relations 'evolved into an integrated trading empire' so much so that the Gulf area stretching from Makran (a part of modern Pakistan) to Al-Ubulla (near modern Basra) was regarded as farj al-Hind or frontier of India. This name farj al-Hind, he explains, actually refers to the course of the realm of the Indian trade at that time. All these trade relations had their linguistic by-products. Wink points out that in Arabic, words of Indian origin are mostly for spices, perfumes, and medicines. Besides, there are other areas where we can still find words of Hindi origin. For instance, in Bahrain several technical measuring terms still in use in the gold and jewelry business are of sub-continental origin, e.g., daram 'gold-tester' tola unit of weight (Holes, 2001). While India exported spices, gold, and swords to Arabia, Arabia exported warriors to India at a much later date. These Arab warriors who served in India for years also brought Hindi words to the Arab lands. How these Arabs did learned Urdu / Hindi and then carried it to their native land across the Arabian Sea?

These Arabs came to work as warriors in some princely states of India. According to Khalidi (1996), Hadramawt Arabs were present in the armies of Hyderabad and other Indian states in the $18^{\text {th }}$ century. He explains that it was the lure of wealth that attracted the Hadramis to Hyderabad. These Arabs married local women and in due course, there was a large number of local-born Arabs. Some of these Hadrami Arabs who served as warriors in India founded the Qu'aiti Sultanate of Shihr and Mukalla in Hadramawt (1902-1967). The relationship between Hyderabad and Hadramawt influenced life in Qa'iti Sultanate. Khalidi records that in Qa'iti Sultanate, Urdu was widely understood in the streets, the curry was popular and some women even wore saris. But, this role of Arabs as soldiers and guards in Hyderabad and other Indian states began to decline with the rise of the British Empire in India, explains Khalidi. However, these political changes did not weaken the influence of Urdu. With the expansion of the British Empire, the relations between India and the Persian Gulf took a new dimension and gave birth to another phase in the gradual development of Urdubic.

As a British colony, India gained importance in the Arabian Sea, the trucial states, and in the British protectorates. At that time the Indian rupee was the principal currency in the Gulf, Indian 
stamps were used (overlaid with state names) ... Urdu (Hindustani) words infiltrated the Arabic coastal dialects. (Leonard, 2003). This infiltration of Urdu words occurred through Indians who came there to work as public servants. According to Holes (2001), a small army of Indian clerks and managers ran most of the Bahrain public services until the late 1960s ...communication with Indian workmen and servants was often conducted in a kind of Arabic based pidgin". In addition to Bahrain and Yemen, Oman too had this Urdu / Hindi influence as a result of long-continued intercourse with the people of India, particularly in the terms used in the trades; this is perhaps more apparent in the sea-coast towns (Jayakar, 1989). Thus, in the light of these observations, the infiltration of Urdu / Hindi words in the Gulf Arabic during the days of the Indo-Arab trading empire, Qa'iti Sultanate, and the British Empire was not a large-scale phenomenon. It was confined to certain areas and situations of contact. After the discovery of oil, this infiltration and diffusion gained momentum with the arrival of a large number of workers from South Asia and the surrounding regions.

As a result of the large-scale migration of Urdu/Hindi speakers from the Indian sub-continent, Urdu gained importance in the Persian Gulf. Today, it is spoken in the Persian Gulf not only by its native speakers from Pakistan and India but also by workers from Bangladesh, Afghanistan, Iran, and Kerala. Workers from these regions don't speak the Urdu language at home or outside the home in their native lands. Leonard (2003) records that an encyclopedia salesman reported that he had to laugh at the way Filipinos, Thais, Egyptians, Palestinians, and Iranis spoke Urdu. On account of this widespread diffusion, it seems to be second to Arabic in having the largest speakers in the Persian Gulf. This is what the statistics seem to state that the Urdu / Hindi community is the second-largest community in the Gulf. For instance, in 2004, of the total 12.5 million foreigners in the G.C.C countries; Indians and Pakistanis were 5million, according to the Egyptian Central Agency for Public Mobilization and Statistics 2004 (as cited in Kapiszewski, 2006). This large presence of Urdu/Hindi speakers in the Gulf gets social acknowledgment in different forms.

There are places in the Arab countries of the Persian Gulf, like Al Ain in Abu Dhabi, where signboards are written in three languages: Arabic, English, and Urdu. Google added Urdu and Hindi among the optional languages for Google UAE. Moreover, there appeared Arab poets and singers who used Urdu in their art. Adil Farooq's Album Daastaan (Kadry, 2015) and Dr. Zubair Farooq Al Arshy's Urdu poetry are the recent examples of this phenomenon (Khanzada, 2013). Thus, the SouthAsian immigrant workers have brought to the Gulf not only their skills but also their language.

Among immigrant workers, maids have played an important role in bringing Urdu to the very homes and tents of the Arabs. Monshipouri (2009) explains that many young UAE nationals are now well-acquainted with Hindi, having been brought up by Asian caregivers. In addition to the maids, marriages between Arabs and Indians have also played a significant role in changing the linguistic make-up of the Arabs' homes. According to Dev (1998), about 10000 Gulf Arabs have married Hyderabad girls. Leonard explains that there have been many marriages between Arabs and young Muslim women from India's Hyderabad state, so South Asian culture is part of the home life as well as the work-life of many UAE Arabs. This familial association with Urdu, based on maids' work and marriages (and we may even include family drivers), makes the Persian Gulf a foster-home for Urdu and Urdubic. In addition to the people from the Indian sub-continent, Urdu/Hindi movies and TV channels have also played their role in taking Urdu/Hindi to the very homes of the Arabs. This diffusion of Urdubic across the Arab countries of the Persian Gulf has alarmed Arab linguists. But, before we further continue our sociolinguistic discussion of Urdubic, it seems germane to stop for a while and peruse what some linguists have said about some of the linguistic features that these largescale and time-honored interactions between the Arabs and the south-Asians have produced.

\section{Some Salient Aspects of Linguistic Reduction \& Simplicity in Urdubic:}

Linguistic studies of Urdubic reveal that Arabic and Urdu/Hindi are the main constituents of Urdubic. Smart (1990) was among the first to study Urdubic. He called it Gulf pidgin (GP). Identifying the areas of GP, he explains that it exists in slightly varying forms along the eastern Arabian seaboard from Kuwait to Oman, and also inland in Saudi Arabia itself. But, he left it to others to ascertain its status as pidgin. Næss (2008) called it Gulf Pidgin Arabic (GPA). She systematically studied it and concluded that it can be called an incipient pidgin variety. Both of them hold that Gulf Arabic is the superstrate language of Urdubic and Urdu/Hindi is the main substrate language along with other languages from the Indian sub-continent. She explains that more than $95 \%$ of the GPA lexicon comes from Gulf Arabic. But, this GPA lexicon is used by migrant workers in their way which is defined by 
over-generalization and interruptions from their mother-tongue structures. For instance, the following examples from Smart (1990) show how simplification is taking the form of over-generalization:

Wajid beet ruh that Many houses went down (were destroyed).

As'ar seer Prices came down.

As'ar foog ma'fi Prices are not high.

Ba'deen kansal zawaj mal-ana Then my marriage will be canceled.

These examples show how Gulf Arabic words are sometimes contextually misplaced in Urdubic spoken by the immigrant workers. For instance, in the daily lives of the workers in the Gulf, the verb kansel is normally used in the context of cancellation of visa. But, they may over-generalize and use it when they want to refer to divorce or ending a war, as in Lazim fi kansal hadha harb this war should be stopped (Smart, 1990). Another aspect of simplification in Urdubic is the feature of reduplication. In a pidgin, reduplication is used for the sake of emphasis (Todd, 2001). Some of the instances of reduplication in Urdubic are: surrah surrah / sari, sari (quick, quick), jildi, jildi (quick, quick) shwayy shwayy (little by little, slowly) and seem, seem (same from English) (Smart, 1990). The word jaldi mentioned in these examples is from Urdu. There are other examples of Urdu words being used in Urdubic such as the word robiya (rupee, instead of dirham or riyal), poratha (a type of bread), Salona (curry), and seedha (straight). Holes (2001) discusses these borrowings from Urdu/Hindi and other Indian languages into Bahraini dialect and classifies them into employment-related domestic, clothes, and food. Thus, these words belong to certain social and professional domains. When talking with the immigrant workers, the Arabs may use these borrowings to ease intelligibility. For instance, robiya is used by the Arab vendors in Saudi Arabia, who usually mix Urdu and Arabic codes to attract their customers from India and Pakistan. For the convenience of their customers, they use Urdu currency words (in making bargains about fare and price) such as banj robia, (five rupees) das robia (ten rupees) and har maal do robia (everything for two rupees). In addition to these words, workers' mother tongue structures also come into play, as in the case of the verb sawwi which, according to Naess, seems to be used in the Gulf with Urdu structure. Sawwi tarteeb (try to do it), shu sawwi (what to do) are the phrases heard frequently in everyday interaction in the Gulf. The verb sawwi is used in combination with a large number of nouns in various situations, e.g. sawwi kalam (say something) sawwi Masada (give help), sawwi shughal (do the work). In short, sawwi seems to have multifunctionality in Urdubic. Similarly, there are other multifunctional words in Urdubic. For instance, Bakir (2014) has discussed in detail the multifunctionality of fii in GPA.

Talking about the use of sawwi in Urdubic or GPA, Næss opines that it is a light verb and that these types of verbal constructions are very common in South Asian languages such as Urdu, one of the main substrate languages for GPA, and the structure may be borrowed into GPA from there. When we look into Urdu for a similar construction, we find the verb Karna (to do) or Karo (do). This seems to be the equivalent of Arabic sawwi. Urdu speakers in the Gulf, when talking among themselves, use the verb Karo with Arabic nouns such as Masada (help), as in Masada Karo (give help). In addition to lexicon, this influence of mother tongue structure seems to play an important part in defining the sound system of Urdubic.

Since a pidgin combines diverse linguistic influences, we cannot expect to find a single phonological system in a new pidgin. In Urdubic, there seems to be "two phonological systems in play: that of the native speakers who may modify his or her normal pronunciation to ease intelligibility; and that of the pidgin speaker, whose success in accurately imitating the sounds of the target language may only be partial" (Smart, 1990). As in ana sawwi nadīp, sawwi nadīp, sawwi ūti I clean; clean and iron (Naes, 2008) fricative $f$ is replaced by plosive $p$ because of mother tongue influence.

Another example is the pronunciation of $/ w / a s / v /$ by speakers of languages which only have the latter sound in their phonological inventory" (Naess, 2008). Thus, on account of reduction, according to Naess (2008), 29 phonemes of GA have been reduced to 18 in GPA or Urdubic and the distinction between short and long vowels appears to have been neutralized. In addition to the phonological system, this feature of reduction is seen in the case of negatives: only one negation, mafi, for all instances of forming negatives, whether negating nouns, finite verbs, or imperatives (Naess, 2008). With all these and other reduced and simplified forms, Urdubic, not only continues to exist in everyday life in the Gulf but has also found expression in the Gulf media. Smart (1990) based his study on the Urdubic cartoons published in the newspapers of the UAE. Urdubic has been a 
source of fun in a Kuwaiti TV comedy Ashshug, broadcast in 2002, (Suleiman, 2004). Besides, some songs combine Arabic and Urdu lines: Habibi Daah (Nari Nari) by an Egyptian Arab Hisham Abbas and Kaho na kaho by Amir Jamil, a Pakistani working in Jeddah are a few examples (Ramkumar, 2005). This situation of language contact penetrating the homes and media of the Arabs has raised the cultural concerns of heritage experts and Arab linguists about the purity of Arabic. It may be a serious issue of language impurity for them.

\section{Urdubic as a Threat}

Arabs' strong sense of self-identity for their culture and language is well known (Bassiouney \& Katz, 2012; Duri, 2012). Concern for preserving the purity of the Arabic language seems to have been common among ancient and modern Arabs. In modern times, one major threat to the purity of the Arabic language felt across the Arab world is English. The Egyptian poet Hafiz Ibrahim's poem alLughah al-'arabiyyah tan'a hazzaha bayn ahliha (The Arabic Language Laments its Fate among its People) is an instance of this stance (as cited in Hartman, 2010). However, some linguists and scholars of Arabic also take Urdubic as a threat to the purity of Arabic in the cosmopolitans of the Persian Gulf. Suleiman (2004) expresses his concern over this "foreign linguistic flood". He is afraid that Arabic is being abandoned by its native sons and daughters who seem to prefer the lure of other tongues, mainly English. He points out that many Gulf Arab children are not able to speak Arabic properly because they have been used to Gulf Pidgin through child-minders at home. He further points out that children who spend long hours in the care of such staff have been observed to have a deficient command of the language. It was Hellyer (2008, Nov 10), a heritage expert in the UAE, who coined the word Urdubic for the first time to talk about threats to the national identity of the UAE. He observes that a new lingua franca has emerged, and is spreading... I call it Urdubic, though others may have their name for it. Hellyer holds that the national identity of the UAE is threatened by globalization and Urdubic. So, this is one view that takes Urdubic as a threat. However, there is another angle of looking at Urdubic.

\section{Resistance of Arabic Language amid Foreign Linguistic Threats}

The second view sees Arabic as umm-ul-lughat or mother of all languages having some intrinsic strength to survive among foreign linguistic influences. According to this view threats from foreign languages are not new to Arabic. If we look back into the past, Arabic had similar threats in the past as well. Hassim (2010) reports about a similar situation in medieval times when due to "the increased interaction between Arabs and non-Arabs through trade, education and military expeditions, corruptions in the Arabic language became more and more prevalent. The instances of intermarriages between Arabs and non-Arabs grew rapidly... a new broken form of Arabic arose... al-Jahiz called the new broken form the language of half-breeds (al-muwalladin) and the common people. The very fact that Arabic culture and language have survived in the Persian Gulf despite being exposed to foreign linguistic and cultural influences seems to speak of some kind of intrinsic strength and buoyancy of Arab culture. Altwaijri (1998) argues that a hallmark of the Arab-Islamic culture is its openness to the cultures of the world while jealously preserving its immutable origins. Arabs have been traveling far and wide for religion, education, trade, and business. The present-day plural society in the fastdeveloping Arab countries of the Persian Gulf seems to be an instance of the 'openness' of Arab culture to the cultures and languages of the world. Moreover, some thinkers seem to take Urdu as a daughter language of Arabic. Urdu may not be a foreign language for them as English is. They seem to have a patronizing attitude towards Urdu and Urdubic. The Arab poet of Urdu Dr. Zubair Farooq $\mathrm{Al}$ Arshy seems to hold this view. He believes that "Urdu is a sweet and a rich language that has firm roots in Arabic" (Kazmi, 2000). It may be due to this sense of attachment between Arabic and Urdu that some Arabs don't appear to take Urdubic as an antithesis of Arabic or a threat to Arabic. To explain the status of Urdu in the Gulf, Khan (2006) uses the metaphor of a daughter returning to her parents' home. He explains that as Urdu / Hindi expands globally and most significantly in the Middle East, one can view this phenomenon as the reverse migration of a synthetic finished product of India whose basic ingredients had come from the Middle East in the remotest antiquity-a daughter returning home. So, these are the two different views that the Arabs have concerning Urdubic. Those who take Urdubic as a threat seem to look at the magnitude of foreign influences. The others look at the strength, soundness, flexibility, and buoyancy of Arab culture and the Arabic language. 
Thus, the current study has surveyed the views of linguists, heritage experts, and anthropologists regarding Urdubic. In other words, it has attempted to look at the past and present of Urdubic. What is the future of Urdubic? It may be too early to talk about its future. But, there are social, geographical, and economic determinants that may indicate certain aspects of the future of Urdubic.

\section{Future of Urdubic:}

The future of Urdubic involves a complex network of social, geographical, and economic factors. According to Crystal (1997), a pidgin lasts for only a few years, and rarely for more than a century. They die when the original reason for communication diminishes, as communities move apart, or one community learns the language of the other. Are the two communities (the Gulf Arabs and the SouthAsians working in the Gulf) going to move apart in near future? One factor that has brought together the Arabs and the South-Asian workers in the Gulf is the oil-based development. Is this reason for communication going to diminish?

The Persian Gulf is among the regions with the greatest crude oil reserve in the world, according to the Annual Statistical Bulletin of OEPEC (2009). A continuation of the oil boom may entail the presence of foreign workers in the Gulf despite the nationalistic employment policies such as Saudization, Emiratization, and Omanization. Moreover, the Gulf cannot rely on oil revenues for good. For solid economic growth, the Gulf governments are developing business and trade in the region. They want the less-developed parts of the region to be like Europe, Japan, Singapore, and the rest of the industrialized world. (His Highness Sheikh Muhammad bin Rashid al-Maktoum, vice president and prime minister of the U.A.E, January 12, 2008). King Abdullah Economic city in the KSA may be a product of a similar vision. Malecki \& Ewers (2007) call such a visual world city aspirations of the Gulf governments. Nurunnabi (2017) and Amirat \& Zaidi (2020) discuss in detail Vision 2030 of KSA. The region is trying to move from an oil-based economy to a knowledge-based economy. In the face of this vision of industrialization and the continuation of the oil boom, total indigenization and nationalization of labor may not be possible in near future. Jordeini (2005) argues that for the foreseeable future, it is likely that the oil-producing Gulf countries will continue to be reliant upon large numbers of guest workers, despite nationalistic policies and programs to reduce them. Besides, the lack of local skilled labor and what Jordeini (2005) calls racialization of c1ertain jobs are other hurdles to total nationalization of labor. Racialisation of certain jobs means certain jobs become associated with certain races. This association may take the form of stigmatization and discourage the native Arabs from taking such jobs. For instance, taxi driving in the UAE has been associated with Pathans from Pakistan and Afghanistan. As, Nichols (2008) records, one taxi driver thought 80 percent of the cab drivers in Dubai were Pashtuns. Similarly, working in cafeterias in the UAE has been associated with Keralites or Malayali people. Besides, there is still another reason which may contribute to the continuity of the survival of Urdubic - the close geographical proximity between the Gulf and the Indian sub-continent.

The two communities (Urdu/Hindi speakers and the Gulf Arabs) may not move apart because they are bound by close geographical proximity, history, culture, and religion. Even if the present economic conditions change in the Gulf, this determinant may continue to play its role in bringing them together as it did in the past. However, this very factor of close geographical proximity combined with strict immigration laws which generally do not facilitate citizenship to foreign workers may discourage the further development of Urdubic into a creole by keeping the workers and their children frequently in touch with their mother tongue and native culture of the Indian sub-continent because one of the conditions that can lead to creolization is that the "speakers of a pidgin may be put in a position where they can no longer communicate by using their mother tongue" (Todd, 2005). In the case of Urdubic, speakers of superstrate and substrate languages regularly communicate in their mother tongues and this may check the further development or creolization of Urdubic.

\section{Conclusion}

In this paper, we tried to highlight the historical, linguistic, and social aspects of Urdubic. The new pidgin seems to be a by-product of South-Asian workers' large-scale migration to the Gulf and their resultant contact with the Arabs of the Persian Gulf and other Asian workers. Total nationalization of labor may not be possible in the Arab countries of the Persian Gulf due to a lack of indigenous skilled labor and a vision of industrialization. Realization of the vision of industrialization entails bringing in new workers from the surrounding countries which, in turn, may mean continuity of the phenomenon 
of pidginization. However, the close geographic proximity between the Persian Gulf and the Indian sub-continent and the strict immigration laws may check the development of Urdubic into a creole.

\section{References}

Abed, L. G. (2018). Gulf Pidgin Arabic: An Empirical Investigation into its Emergence and Social Attitude (Doctoral dissertation, Trinity College Dublin).

Alghamdi, E. A. (2014). Gulf Pidgin Arabic: A Descriptive and Statistical Analysis of Stability. International Journal of Linguistics, 6(6), 110.

Alshammari, W. F. B. (2018). The Development of and Accommodation in Gulf Pidgin Arabic: Verbal and Pronominal Form Selection (Doctoral dissertation, Indiana University).

Altwaijri, A. O. (1998, March 4-19). Arab culture and other cultures. Paper presented at Symposium on "Arab Culture and other Cultures". Riyadh: Publications of - ISESCO Retrieved June 11, 2010, from http://www.jeunessearabe.info/IMG/Arab_culture_and_other_cult-en.pdf

Amirat, A., \& Zaidi, M. (2020). Estimating GDP growth in Saudi Arabia under the government's vision 2030: a knowledge-based economy approach. Journal of the Knowledge Economy, 11(3), 11451170 .

Ammon, U. Dittmar, N., Mattheier, K.J. \& Trudgill, P. (2006). Sociolinguistics: an international handbook of the science of language and society. (Vol. 3). ( $\left.2^{\text {nd }} \mathrm{Ed}\right)$. Berlin: Gruyter GmbH \& Co. KG.

Avram, A. A. (2014). Immigrant workers and language formation: Gulf Pidgin Arabic. Lengua y migración/Language and Migration, 6(2), 7-40.

Bakir, M. J. (2014). The multifunctionality of fii in Gulf Pidgin Arabic. Journal of Pidgin and Creole Languages, 29(2), 410-436.

Barotchi, M. (2001). Lingua franca. In Rajend Mestherie (Ed.). Concise encyclopedia of sociolinguistics. (pp. 503-504) Oxford: Elsevier.

Bassiouney, R., \& Katz, E. G. (2012). Arabic language and linguistics. Washington DC: Georgetown University Press.

Crystal, D. (1997). The Cambridge encyclopedia of Language. Cambridge: Cambridge UP.

Dev, L. (1998). Crime, atrocities, and violence against women and related laws and justice. New Delhi: Anmol Publications Pvt Ltd.

Dil, S. A. (2003). Urdu. In William J. Frawley, International encyclopedia of linguistics. $\left(2^{\text {nd }}\right.$ ed). (Vol. 4). (pp. 333--34). New York: Oxford UP.

Duri, A. A. (2012). The historical formation of the Arab nation (RLE: The Arab Nation). Routledge.

Hartman, M. (2010). Hafiz Ibrahim. In Roger Allen (Ed), Essays in Arabic literary biography 1850--1950. (pp. 149--159). Wiesbaden: Harrassowitz.

Hassim, E. (2010). Elementary education and motivation in Islam: perspectives of medieval Muslim scholars, 750-1400 CE. N.Y: Cambridge UP.

Hellyer, P. (2008, Nov 10). How will Arabic be preserved with rules like these? The National. Retrieved June 11, 2010, from http://www.thenational.ae/article/20081110/OPINION/ 529651383

Holes, C. (2001). Dialect, culture, and society in eastern Arabia. Boston: Brill.

Jayakar, A.S.G. (1989). The O'mánee Dialect of Arabic. The Journal of the Royal Asiatic Society of Great Britain and Ireland. New Series, 21, (pp. 649-687). Retrieved December 5, 2010, from http://www.jstor.org/pss/25208948

Jordeini, R. (2005). Middle East Guest Workers. In Gibney, M. J \& Hansen, R. (Ed). Immigration and asylum: From 1900 to the present. (Vol 2) (pp. 347-696) Santa Barbara, California: ABC-CLIO.

Kapiszewski, A. (2006, 15-17 May). Arab versus Asian migrant workers In the GCC countries. Paper presented at the United Nations Expert Group Meeting on International Migration and Development in The Arab Region. Beirut. Retrieved May 14, 2010, from http://www.un.org/esa/population/meetings/EGM_Ittmig_Arab/P02_Kapiszewski.pdf

Kadry. M. (June 23, 2015). Emirati singer Adel Farooq takes on Bollywood. Khaleej Times. Retrieved December 6, 2020, from https://www.khaleejtimes.com/citytimes/emirati-singer-adel-farooqtakes-on-bollywood

Kazmi, A. (2000, October 6). Facebook, Dr. Mohammed Zubair Farooq Al Arshi. Retrieved April 11, 2011, from http://www.facebook.com/group.php?gid=11405798561

Khalidi. O. (1996). The Arabs of Hadramawt in Hyderabad: Mystics, Mercenaries, and Moneylenders. In A. R Kulkarni, M.A Nayeem and T.R de Souza. (Ed.). Mediaeval Deccan history: commemoration volume in honor of Purshottam Mahadeo Joshi. (pp. 52--76) Bombay: Popular Prakashan Pvt Ltd. 
Khan, A. (2006). Urdu / Hindi: an artificial divide. African heritage, Mesopotamian roots, Indian culture, and British colonialism. NY: Algora Publishing.

Khanzada. R.Z. A. (Oct 30, 2013). Dr. Zubair finds Urdu to be the best medium of communication. Geo News. Retrieved December 6, 2020, from https://www.geo.tv/latest/65735-dr-zubair-finds-urduto-be-best-medium-of-communication

Kumar, R. (2004). Mahatma Ggandhi at the close of the twentieth century. New Delhi: Anmol Publications Pvt Ltd.

Leonard, K. (2003). South Asian workers in the Gulf: jockeying for places. In Richard. Warren Perry \& Bill Maurer (Ed.). Globalization under construction: government law and identity. (pp.129-170). Minnesota: University of Minnesota Press.

Malecki, E.J \& Ewers, M.C. (2007). Labor migration to world cities: with a Research Agenda for the Arab Gulf. Progress in Human Geography, vol. 31, 4: pp. 467-484. Retrieved December 5, 2010, from http://ipac.kacst.edu.sa/eDoc/eBook/4495.pdf

Malmkjær, K. (2000). Creoles and pidgins. In Kristen Malmkjær (Ed), the linguistics encyclopedia. ( $2^{\text {nd }}$ Ed.). London: Routledge.

Monshipouri, M. (2009). Muslims in global politics: identities, interests, and human rights. Philadelphia: University of Pennsylvania Press.

Muhammad, S. (January 12, 2008). Our ambitions for the Middle East. Retrieved December 5, 2010, from http://www.sheikhmohammed.co.ae/

Næss. U.G (2008). "Gulf Pidgin Arabic": individual strategies or a structured variety? A study of some features of the linguistic behavior of Asian migrants in the Gulf countries. (M.A Thesis, University of Oslo, 2008). Retrieved September 17, 2010, from http://www.duo.uio.no /publ/IKOS/2008/86617/Naess_Master.pdf

Nichols, R. (2008). A history of Pashtun migration1775-2006. New Jersey: Oxford UP.

Nurunnabi, M. (2017). The transformation from an oil-based economy to a knowledge-based economy in Saudi Arabia: the Direction of Saudi Vision 2030. Journal of the Knowledge Economy, 8(2), 536564.

OPEC. (2009). Annual Statistical Bulletin, 2009. OPEC. Retrieved Sept, 18, 2010, from http://www.opec.org/opec_web/static_files_project/media/downloads/publications/ASB2009.pdf.

Ramkumar. K.S. (June 24, 2005). Jeddah's Amir Jamal Makes Waves in Bollywood. Arab News. Retrieved December 6, 2020, from https://www.arabnews.com/node/268966

Sherwani, H.K., Joshi, P.M., Nayeem. M.A (1975). Studies in the foreign relations of India, from the earliest times to 1947: Prof. H.K. Sherwani felicitation volume. Hyderabad: State Archives, Govt. of Andhra Pradesh.

Suleiman, Y. (2004). A war of words: language and conflict in the Middle East. Cambridge: Cambridge UP.

Smart, J.R. (1990). Pidginization in Gulf Arabic: A First Report. Anthropological linguistics. Vol. 32, pp. 83-119 Retrieved September 18, 2010, from http://www.jstor.org/stable/30028141

Todd, L. (2001). Pidgins and creoles; an overview. Concise encyclopedia of sociolinguistics. Oxford: Elsevier.

Todd, L. (2005). Pidgins and creoles. Taylor \& Francis e-Library. Retrieved, March 5, 2011, from http://books.google.com.pk/books?id=yHUwIVvXB4MC\&printsec=frontcover\&dq=pidgins\&hl= en\&ei=7HeNTZvVJISnrAfsuIzcDQ\&sa=X\&oi=book_result\&ct=result\&resnum=1\&ved=0CCcQ 6AEwAA\# $=$ onepage \&q $\& \mathrm{f}=$ false

Wink, A. (2002). Al-Hind: the making of the Indo-Islamic World. (Vol. 1). USA: Brill.

Zacharias, A. (2010, May 2) new lingo sets tongues wagging. The National, Abu Dhabi. Retrieved September 19, 2010, from http://www.thenational.ae/apps/pbcs.dll/article?AID=/20100502/ NATIONAL/705019866/0/business 